\title{
Distribution of Paget's disease in England, Wales and Scotland and a possible relationship with vitamin $\mathrm{D}$ deficiency in childhood
}

\author{
D. J. P. BARKER AND M. J. GARDNER \\ Community Medicine, University of Southampton
}

\section{SUMMARY}

Within England, Wales, and Scotland there are regional variations in hospital discharge rates for Paget's disease (osteitis deformans). Successive cohorts born after the 1880 s show a progressive fall in mortality from Paget's disease. Because of the epidemiological similarity between the disease and rickets it is suggested that vitamin $\mathbf{D}$ deficiency in childhood may be a predisposing influence.

\section{INTRODUCTION}

Paget's disease (osteitis deformans) is a cause of bone pain, fractures, and deformity in the elderly. The aetiology is unknown. Although the clinical syndromes associated with the disease are uncommon, subclinical forms are common in Britain. In Southampton, for example, a recent review of $800 x$-rays of persons aged 55 years or more revealed $6 \cdot 1 \%$ as having radiological signs of the disease (Guyer, Barker, and Gardner, 1974). This high frequency is in accord both with other radiological surveys (Pygott, 1957) and with necropsy studies (Collins, 1956).

This paper describes observations on the regional distribution of hospital discharge rates and the changing mortality rates of the disease in England, Wales, and Scotland.

\section{RESULTS}

\section{Hospital Discharge Rates}

Table I shows annual rates of hospital discharge of patients in whom the principal diagnosis was Paget's disease. Rates for the ten regions in England and Wales are derived from the $10 \%$ sample of discharges and deaths recorded by the Hospital In-patient Enquiry (HIPE). There were 493 discharges during the five years 1966-70. Rates for the six regions in Scotland are derived from Scottish Home and Health Depar tment records of all hospital discharges during the 12 years 1961-72. There

TABLE I

ANNUAL HOSPITAL DISCHARge RATES OF PATIENTS WITH PRINCIPAL DIAGNOSIS OF PAGET'S DISEASE

\begin{tabular}{|c|c|c|c|c|c|c|}
\hline & \multicolumn{4}{|c|}{ Region } & No. of Discharges & $\begin{array}{l}\text { Average Annual Discharge } \\
\text { Rate per Million }\end{array}$ \\
\hline $\begin{array}{l}\text { England and Wales* } \\
(1966-70)\end{array}$ & $\begin{array}{l}\text { North } \\
\text { Yorkshire and Hum } \\
\text { North-west } \\
\text { East Midlands } \\
\text { West Midlands } \\
\text { East Anglia } \\
\text { South-east... } \\
\text { South-west } \\
\text { Wales (South-east) } \\
\text { Wales (Remainder) }\end{array}$ & $\begin{array}{l}\text { berside } \\
. \\
\therefore \\
\therefore \\
\therefore \\
\therefore \\
\therefore \\
\therefore\end{array}$ & $\begin{array}{l}. \\
\ldots \\
\cdots \\
\cdots \\
\cdots \\
\because \\
\cdots\end{array}$ & $\begin{array}{l}\cdots \\
\cdots \\
\cdots \\
\cdots \\
\cdots \\
\cdots \\
\cdots\end{array}$ & $\begin{array}{r}39 \\
80 \\
76 \\
25 \\
31 \\
11 \\
161 \\
37 \\
22 \\
11\end{array}$ & $\begin{array}{l}26 \\
37 \\
25 \\
16 \\
13 \\
14 \\
21 \\
22 \\
25 \\
31\end{array}$ \\
\hline Scotland $+(1961-72)$ & $\begin{array}{l}\text { Crofting Counties } \\
\text { North Eastern } \\
\text { East Central } \\
\text { West Central } \\
\text { Border Counties } \\
\text { South Western }\end{array}$ & $\begin{array}{l}\because \\
\because \\
\because \\
\therefore\end{array}$ & $\begin{array}{l}. \\
\because \\
\because \\
\cdots \\
\cdots\end{array}$ & $\begin{array}{l}\cdots \\
\because \\
\cdots \\
\cdots\end{array}$ & $\begin{array}{r}29 \\
241 \\
309 \\
699 \\
11 \\
35\end{array}$ & $\begin{array}{r}9 \\
24 \\
20 \\
23 \\
9 \\
20\end{array}$ \\
\hline
\end{tabular}

*Data from Hospital In-patient Enquiry and 1968 Annual Statistical Review for England and Wales (rates multiplied by adjustment factors given in HIPE annual reports).

†Data from Scottish Home and Health Department and 1966 Census of Scotland. 
were 1,336 records of patients with Paget's disease during this time. On 12 the address was either not recorded or was outside Scotland. Of the 1,324 records remaining, 201 were of subsequent admissions of patients already admitted for Paget's disease during the 1961-72 period. In order that the Scottish data should be comparable with that from England and Wales records of subsequent admissions are included in the rates shown in Table I.

In Wales and the three northern regions of England the rates are higher than those in the central and southern regions of England. In Scotland

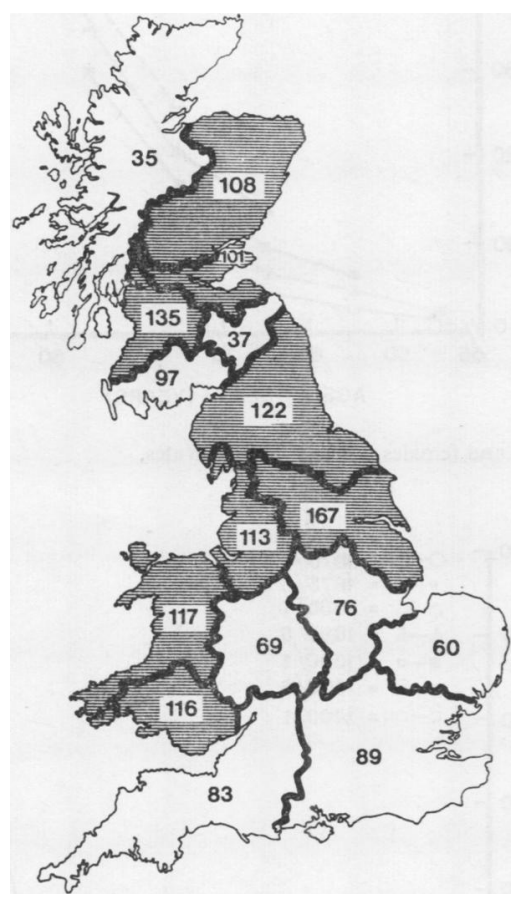

FIG. 1. Standardized morbidity ratios for Paget's disease in England, Wales and Scotland (hospital discharge data). the rates for the Crofting Counties region in the north and for the Border Counties region in the south are markedly lower than those in the remaining regions. The rate for Yorkshire and Humberside (37 per million) is the highest for any of the regions in England, Wales or Scotland.

Figure 1 shows the discharge rates expressed as standardized morbidity ratios, which were calculated in the same way as standardized mortality ratios and enable age-sex standardized comparisons between the regions in England, Wales, and Scotland. The highest standardized morbidity ratios are in Yorkshire and Humberside (167), the West Central region of Scotland (135), and the Northern region of England (122). The five regions in the south and east of England have standardized morbidity ratios below 100 , as do the Crofting Counties, Border Counties, and South Western regions of Scotland.

\section{COHORT TRENDS}

(a) Paget's Disease Since 1950 the Registrar General's Annual Statistical Review for England and Wales (1951-70) has published the number of deaths from Paget's disease (current ICD number 721) in five-year age groups. During this time there was a marked decline in rates of male deaths but no similar decline was seen in female death rates (Table II). In Scotland during the same period death rates from Paget's disease have declined in both males and females, but more markedly in the former. The fall in male death rates in Scotland (from 3.9 to 1.4 ) is greater than the fall in male death rates in England and Wales (from 4.0 to $2 \cdot 6$ ).

Table III shows these mortality data as agespecific death rates for cohorts of males and females born at around the same times in England and Wales and in Scotland. The data for males and females combined are shown in Figure 2. There is a marked rise in the death rates with increasing age, and male rates are higher than female rates. In

TABLE II

AVERAGE ANNUAL DEATH RATES PER MILlion FROM PAGET'S DiseASE

\begin{tabular}{|c|c|c|c|c|c|c|c|c|c|}
\hline \multirow[b]{2}{*}{$\begin{array}{l}\text { England } \\
\text { and Wales }\end{array}$} & \multirow[b]{2}{*}{$\begin{array}{l}\text { Males } \\
\text { Females }\end{array}$} & \multicolumn{2}{|c|}{$1951-55$} & \multicolumn{2}{|c|}{$1956-60$} & \multicolumn{2}{|c|}{$1961-65$} & \multicolumn{2}{|c|}{$1966-70$} \\
\hline & & $\begin{array}{l}4 \cdot 0 \\
3 \cdot 5\end{array}$ & $\begin{array}{l}(423) \\
(403)\end{array}$ & $\begin{array}{l}3 \cdot 4 \\
3 \cdot 7\end{array}$ & $\begin{array}{l}(373) \\
(427)\end{array}$ & $\begin{array}{l}3 \cdot 1 \\
3 \cdot 7\end{array}$ & $\begin{array}{l}(359) \\
(443)\end{array}$ & $\begin{array}{l}2 \cdot 6 \\
3 \cdot 7\end{array}$ & $\begin{array}{l}(313) \\
(458)\end{array}$ \\
\hline & Total & $3 \cdot 7$ & (826) & $3 \cdot 6$ & $(800)$ & $3 \cdot 4$ & (802) & $3 \cdot 2$ & (771) \\
\hline \multirow[t]{2}{*}{ Scotland } & $\begin{array}{l}\text { Males } \\
\text { Females }\end{array}$ & $\begin{array}{l}3 \cdot 9 \\
2 \cdot 0\end{array}$ & $\begin{array}{l}\text { (48) } \\
\text { (27) }\end{array}$ & $\begin{array}{l}2 \cdot 6 \\
2 \cdot 2\end{array}$ & $\begin{array}{l}\text { (33) } \\
\text { (29) }\end{array}$ & $\begin{array}{l}2.4 \\
1.9\end{array}$ & $\begin{array}{l}\text { (31) } \\
\text { (25) }\end{array}$ & $\begin{array}{l}1.4 \\
1.3\end{array}$ & $\begin{array}{l}\text { (18) } \\
\text { (18) }\end{array}$ \\
\hline & Total & 2.9 & (75) & $2 \cdot 4$ & (62) & $2 \cdot 2$ & (56) & $1 \cdot 4$ & (36) \\
\hline
\end{tabular}


TABLE III

COHORT MORTALITY RATES PER MILLION FROM PAGET'S DISEASE IN FIVEY-YEAR PERIODS DURING

(a) Males in England and Wales

\begin{tabular}{|c|c|c|c|c|c|c|c|}
\hline \multirow{2}{*}{$\begin{array}{l}\text { Cohort } \\
\text { born } \\
\text { around* }\end{array}$} & \multicolumn{7}{|c|}{ Age at Death } \\
\hline & $55-$ & $60-$ & $65-$ & $70-$ & $75-$ & $80-$ & $85+$ \\
\hline $\begin{array}{l}1865 / 6 \\
1870 / 1 / 1 \\
1877 / 6 \\
1880 / 1 \\
1885 / 6 \\
1890 / 1 \\
1895 / 6 \\
1900 / 1 \\
1905 / 6 \\
1910 / 1\end{array}$ & $\begin{array}{l}1.9 \\
1.7 \\
1.2 \\
0.7\end{array}$ & $\begin{array}{l}9 \cdot 0 \\
4.9 \\
2.4 \\
2.0\end{array}$ & $\begin{array}{r}17.4 \\
11.0 \\
7.1 \\
4.9\end{array}$ & $\begin{array}{l}31 \cdot 1 \\
25 \cdot 4 \\
22 \cdot 0 \\
17 \cdot 6\end{array}$ & $\begin{array}{l}57.8 \\
53.7 \\
44.8 \\
35.5\end{array}$ & $\begin{array}{l}71 \cdot 0 \\
76 \cdot 2 \\
84 \cdot 0 \\
68 \cdot 4\end{array}$ & $\begin{array}{r}70.6 \\
73.1 \\
136.7 \\
137.9\end{array}$ \\
\hline
\end{tabular}

(b) Females in England and Wales

\begin{tabular}{|c|c|c|c|c|c|c|c|}
\hline \multirow{2}{*}{$\begin{array}{c}\text { Cohort } \\
\text { born } \\
\text { around* }\end{array}$} & \multicolumn{7}{|c|}{ Age at Death } \\
\hline & $55-$ & $60-$ & $65-$ & $70-$ & $75-$ & $80-$ & $85+$ \\
\hline $\begin{array}{l}1865 / 6 \\
1870 / 1 \\
1875 / 6 \\
1880 / 1 \\
1885 / 6 \\
1890 / 1 \\
1895 / 6 \\
1900 / 1 \\
1905 / 6 \\
1910 / 1\end{array}$ & $\begin{array}{l}2.2 \\
0.7 \\
0.9 \\
0.4\end{array}$ & $\begin{array}{l}4 \cdot 1 \\
4 \cdot 4 \\
2 \cdot 4 \\
2 \cdot 6\end{array}$ & $\begin{array}{r}11 \cdot 5 \\
9.1 \\
6.9 \\
4.1\end{array}$ & $\begin{array}{l}22.7 \\
17.6 \\
13.9 \\
11 \cdot 2\end{array}$ & $\begin{array}{l}29 \cdot 2 \\
30 \cdot 6 \\
29 \cdot 5 \\
26 \cdot 2\end{array}$ & $\begin{array}{l}47 \cdot 7 \\
50 \cdot 5 \\
58 \cdot 9 \\
59 \cdot 1\end{array}$ & $\begin{array}{l}54 \cdot 2 \\
68.0 \\
71 \cdot 9 \\
80 \cdot 4\end{array}$ \\
\hline
\end{tabular}

(c) Males in Scotland

\begin{tabular}{|c|c|c|c|c|c|c|c|}
\hline \multirow{2}{*}{$\begin{array}{c}\text { Cohort } \\
\text { born } \\
\text { around* }\end{array}$} & \multicolumn{7}{|c|}{ Age at Death } \\
\hline & $55-$ & $60-$ & $65-$ & $70-$ & $75-$ & $80-$ & $85+$ \\
\hline $\begin{array}{l}1865 / 6 \\
1870 / 1 \\
1875 / 6 \\
1880 / 1 \\
1885 / 6 \\
1890 / 1 \\
1895 / 6 \\
1900 / 1 \\
1905 / 6 \\
1910 / 1\end{array}$ & $\begin{array}{l}6.7 \\
1.4 \\
0.0 \\
0.0\end{array}$ & $\begin{array}{l}4.0 \\
1.9 \\
0.0 \\
0.0\end{array}$ & $\begin{array}{r}14.6 \\
7.3 \\
14.2 \\
6.0\end{array}$ & $\begin{array}{r}40.5 \\
35.9 \\
16.6 \\
0.0\end{array}$ & $\begin{array}{l}65 \cdot 8 \\
43 \cdot 5 \\
61 \cdot 2 \\
41 \cdot 5\end{array}$ & $\begin{array}{l}51 \cdot 6 \\
54 \cdot 7 \\
38 \cdot 1 \\
19 \cdot 7\end{array}$ & $\begin{array}{l}57.6 \\
23.4 \\
81.8 \\
60.4\end{array}$ \\
\hline
\end{tabular}

(d) Females in Scotland

\begin{tabular}{|c|c|c|c|c|c|c|c|}
\hline \multirow{2}{*}{$\begin{array}{l}\text { Cohort } \\
\text { born } \\
\text { around* }\end{array}$} & \multicolumn{7}{|c|}{ Age at Death } \\
\hline & 55- & $60-$ & $65-$ & $70-$ & $75-$ & $80-$ & $85+$ \\
\hline $\begin{array}{l}1865 / 6 \\
1870 / 1 \\
1875 / 6 \\
1880 / 1 \\
1885 / 6 \\
1890 / 1 \\
1895 / 6 \\
1900 / 1 \\
1905 / 6 \\
1910 / 1\end{array}$ & $\begin{array}{l}1.3 \\
2.5 \\
0.0 \\
0.0\end{array}$ & $\begin{array}{l}1 \cdot 5 \\
7.2 \\
1 \cdot 3 \\
1 \cdot 3\end{array}$ & $\begin{array}{r}14.5 \\
10.4 \\
4.9 \\
0.0\end{array}$ & $\begin{array}{r}25 \cdot 2 \\
13 \cdot 1 \\
6 \cdot 2 \\
3.8\end{array}$ & $\begin{array}{r}16.9 \\
9.5 \\
23.8 \\
11.0\end{array}$ & $\begin{array}{r}6 \cdot 7 \\
22 \cdot 9 \\
16 \cdot 0 \\
23 \cdot 7\end{array}$ & $\begin{array}{r}0 \cdot 0 \\
38 \cdot 1 \\
62 \cdot 2 \\
53 \cdot 1\end{array}$ \\
\hline
\end{tabular}

*Cohorts are defined by the mid-point in the range of years during which members of the cohort were born. For example, during which members of the cohort were born. For example,
the $1890 / 1$ cohort includes individuals born from 1886 to 1895 .

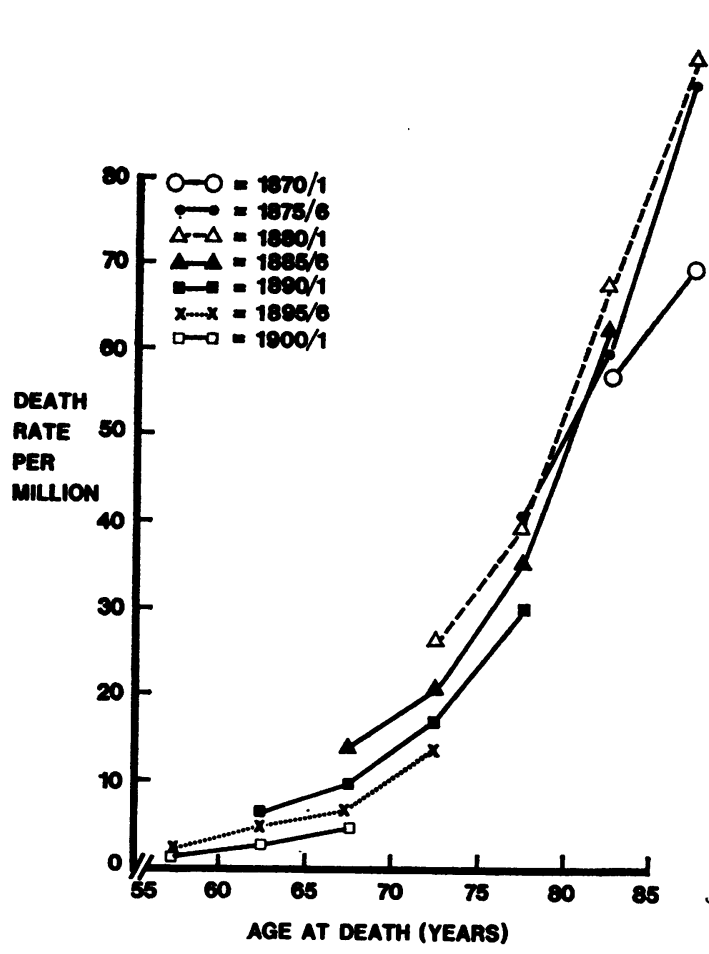

(a) Males and females in England and Wales.

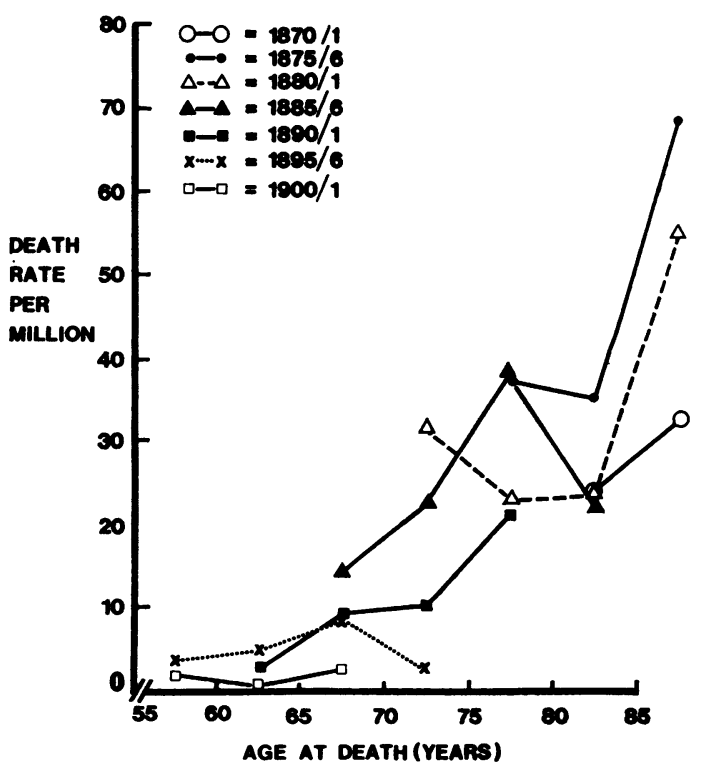

(b) Males and females in Scotland. FIG. 2. Cohort mortality from Paget's disease in five-year periods, 
TABLE IV

AVERAGE ANNUAL DEATH RATES PER MILLION FROM MALIGNANT TUMOURS OF BONE AMONG PERSONS AGED 55 YEARS AND OVER

\begin{tabular}{|c|c|c|c|c|c|c|c|c|c|}
\hline \multirow{3}{*}{$\begin{array}{l}\text { England } \\
\text { and Wales }\end{array}$} & \multirow{3}{*}{$\begin{array}{l}\text { Males } \\
\text { Females } \\
\text { Total }\end{array}$} & \multicolumn{2}{|c|}{$1951-55$} & \multicolumn{2}{|c|}{$1956-60$} & \multicolumn{2}{|c|}{$1961-65$} & \multicolumn{2}{|c|}{$1966-70$} \\
\hline & & $\begin{array}{l}62 \cdot 7 \\
37 \cdot 5\end{array}$ & $\begin{array}{l}(1,284) \\
(1,042)\end{array}$ & $\begin{array}{l}51 \cdot 0 \\
31 \cdot 4\end{array}$ & $\begin{array}{r}(1,122) \\
(946)\end{array}$ & $\begin{array}{l}40.7 \\
26.6\end{array}$ & $\begin{array}{l}(973) \\
(860)\end{array}$ & $\begin{array}{l}36 \cdot 4 \\
22 \cdot 2\end{array}$ & $\begin{array}{l}(925) \\
(765)\end{array}$ \\
\hline & & $48 \cdot 2$ & $(2,326)$ & $39 \cdot 7$ & $(2,068)$ & $32 \cdot 6$ & $(1,833)$ & $28 \cdot 2$ & $(1,690)$ \\
\hline \multirow[t]{2}{*}{ Scotland } & $\begin{array}{l}\text { Males } \\
\text { Females }\end{array}$ & $\begin{array}{r}106 \cdot 4 \\
64 \cdot 4\end{array}$ & $\begin{array}{l}(231) \\
(187)\end{array}$ & $\begin{array}{l}76 \cdot 2 \\
43 \cdot 8\end{array}$ & $\begin{array}{l}(175) \\
(136)\end{array}$ & $\begin{array}{l}62 \cdot 1 \\
25 \cdot 7\end{array}$ & $\begin{array}{r}(151) \\
(85)\end{array}$ & $\begin{array}{l}47 \cdot 3 \\
23 \cdot 7\end{array}$ & $\begin{array}{r}(121) \\
(83)\end{array}$ \\
\hline & Total & $82 \cdot 4$ & (418) & $57 \cdot 6$ & (311) & $41 \cdot 2$ & (236) & $33 \cdot 7$ & (204) \\
\hline
\end{tabular}

Numbers of deaths are given in parentheses.

England and Wales (Tables IIIa and b) successive cohorts born from around 1880/1 onwards show progressively lower death rates. This occurs in both male and female cohorts. In Scotland (where the number of deaths is fewer) the trend in declining mortality is not so consistent for successive cohorts as it is in England and Wales. However, there is a clear overall decline from the 1880 s onwards. In England and Wales and Scotland mortality rates in cohorts born before the 1880 s show a progressive increase, so that cohorts born during the 1880 s have the highest certified death rates from the disease.

The rates for male and female cohorts combined (Fig. 2) are generally similar in England and Wales and in Scotland, except that Scottish rates are lower after the age of 80 . Rates for females in Scotland are consistently lower than those in England and Wales (Tables IIIb and d). Rates for males in Scotland are similar to those in England and Wales up to the age of 80 , after which the Scottish rates are lower (Tables IIIa and c).

(b) Malignant Tumours of Bone Among males and females aged 55 years and over the rates of deaths certified as due to malignant tumours of bone (current ICD number 170) fell during 1951-70 both in England and Wales and in Scotland (Table IV). In Table $\mathrm{V}$ these death rates are shown as age-specific death rates for successive cohorts. The cohorts are the same as those in Table III, and data for England and Wales and Scotland have been combined. Successive cohorts born from around 1870/1 onwards show progressively lower death rates at each age. This occurs in both male and female cohorts, but the rates for males are generally higher than those for females.

(c) Fractured Neck of Femur Table VI shows mortality attributed to fractured neck of femur (current ICD number N820) among males and females aged 55 years and over in England and
TABLE V

COHORT MORTALITY RATES PER MILLION FROM MALIGNANT TUMOURS OF BONE IN FIVE-YEAR PERIODS DURING 1951-70

(a) Males in England, Wales, and Scotland

\begin{tabular}{|c|c|c|c|c|c|c|c|}
\hline \multirow{2}{*}{$\begin{array}{l}\text { Cohort } \\
\text { born } \\
\text { around* }\end{array}$} & \multicolumn{7}{|c|}{ Age at Death } \\
\hline & $55-$ & $60-$ & $65-$ & $70-$ & $75-$ & $80-$ & $85+$ \\
\hline $\begin{array}{l}1865 / 6 \\
1870 / 1 \\
1875 / 6 \\
1880 / 1 \\
1885 / 6 \\
1890 / 1 \\
1895 / 6 \\
1900 / 1 \\
1905 / 6 \\
1910 / 1\end{array}$ & $\begin{array}{l}32 \cdot 8 \\
24 \cdot 4 \\
21 \cdot 5 \\
19 \cdot 7\end{array}$ & $\begin{array}{l}45 \cdot 6 \\
39 \cdot 9 \\
31 \cdot 7 \\
24 \cdot 2\end{array}$ & $\begin{array}{l}73.8 \\
55.1 \\
40.6 \\
38.8\end{array}$ & $\begin{array}{l}92.1 \\
69.5 \\
60.0 \\
55.9\end{array}$ & $\begin{array}{r}121.5 \\
98.5 \\
82.8 \\
69.4\end{array}$ & $\begin{array}{r}136.2 \\
135.3 \\
95.8 \\
88.6\end{array}$ & $\begin{array}{r}144.1 \\
133.1 \\
131.6 \\
98.7\end{array}$ \\
\hline
\end{tabular}

(b) Females in England, Wales, and Scotland

\begin{tabular}{|c|c|c|c|c|c|c|c|}
\hline \multirow{2}{*}{$\begin{array}{l}\text { Cohort } \\
\text { born } \\
\text { around* }\end{array}$} & \multicolumn{7}{|c|}{ Age at Death } \\
\hline & $55-$ & $60-$ & $65-$ & $70-$ & $75-$ & $80-$ & $85+$ \\
\hline $\begin{array}{l}1865 / 6 \\
1870 / 1 \\
1875 / 6 \\
1880 / 1 \\
1885 / 6 \\
1890 / 1 \\
1895 / 6 \\
1900 / 1 \\
1905 / 6 \\
1910 / 1\end{array}$ & $\begin{array}{l}18 \cdot 8 \\
15 \cdot 0 \\
11 \cdot 2 \\
10.3\end{array}$ & $\begin{array}{l}30.6 \\
20.6 \\
16.9 \\
15.5\end{array}$ & $\begin{array}{l}38.6 \\
31.4 \\
24 \cdot 0 \\
19.8\end{array}$ & $\begin{array}{l}56 \cdot 0 \\
38 \cdot 5 \\
33 \cdot 2 \\
28 \cdot 1\end{array}$ & $\begin{array}{l}69 \cdot 5 \\
60.8 \\
46.3 \\
34.6\end{array}$ & $\begin{array}{l}62 \cdot 8 \\
61 \cdot 5 \\
56 \cdot 2 \\
41 \cdot 5\end{array}$ & $\begin{array}{l}70.4 \\
79.4 \\
59.8 \\
55.6\end{array}$ \\
\hline
\end{tabular}

*See footnote to Table III

Wales. Data for Scotland are not available. Among males the death rates rose between 1951-55 and 1956-60 and then fell again from 1961-65 to 1966-70. Among females there was a rise in death rates in each successive five-year period from 1951-55 to 1966-70. In Table VII these deaths are shown as age-specific death rates for successive cohorts. The cohorts differ from those in Tables III and $\mathrm{V}$ as the available data are 
TABLE VI

AVERAGE ANNUAL DEATH RATES PER MILLION FROM FRACTURED NECK OF FEMUR AMONG PERSONS AGED 55 AND OVER IN ENGLAND AND WALES

\begin{tabular}{|c|c|c|c|c|c|c|c|c|}
\hline \multirow[b]{2}{*}{$\begin{array}{l}\text { Males } \\
\text { Females }\end{array}$} & \multicolumn{2}{|c|}{ 1951-55 } & \multicolumn{2}{|c|}{$1956-60$} & \multicolumn{2}{|c|}{$1961-65$} & \multicolumn{2}{|c|}{$1966-70$} \\
\hline & $\begin{array}{r}79 \cdot 0 \\
159 \cdot 7\end{array}$ & $\begin{array}{l}(1,617) \\
(4,442)\end{array}$ & $\begin{array}{r}97 \cdot 4 \\
205 \cdot 2\end{array}$ & $\begin{array}{l}(2,142) \\
(6,184)\end{array}$ & $\begin{array}{r}94 \cdot 1 \\
212 \cdot 1\end{array}$ & $\begin{array}{l}(2,247) \\
(6,864)\end{array}$ & $\begin{array}{r}83 \cdot 1 \\
231 \cdot 7\end{array}$ & $\begin{array}{l}(2,113) \\
(7,966)\end{array}$ \\
\hline Total & $125 \cdot 4$ & $(6,059)$ & $159 \cdot 8$ & $(8,326)$ & $162 \cdot 0$ & $(9,111)$ & $168 \cdot 5$ & $(10,079)$ \\
\hline
\end{tabular}

Numbers of deaths are given in parentheses

TABLE VII

COHORT MORTALITY RATES PER MILLION FROM FRACTURED NECK OF FEMUR IN TEN-YEAR PERIODS

(a) Males in England and Wales

\begin{tabular}{|c|c|c|c|c|}
\hline \multirow{2}{*}{$\begin{array}{l}\text { Cohort } \\
\text { born } \\
\text { around* }\end{array}$} & \multicolumn{4}{|c|}{ Age at Death } \\
\hline & $55-$ & $65-$ & $75-$ & $85+$ \\
\hline $\begin{array}{l}1863 \\
1868 \\
1873 \\
1878 \\
1883 \\
1888 \\
1893 \\
1898 \\
1903 \\
1908\end{array}$ & $\begin{array}{l}4 \cdot 3 \\
6 \cdot 0 \\
7 \cdot 3 \\
5 \cdot 8\end{array}$ & $\begin{array}{l}43 \cdot 1 \\
53 \cdot 8 \\
52 \cdot 3 \\
42 \cdot 2\end{array}$ & $\begin{array}{l}313 \cdot 8 \\
358 \cdot 8 \\
353 \cdot 7 \\
314 \cdot 9\end{array}$ & $\begin{array}{l}1,164 \cdot 7 \\
1,463 \cdot 5 \\
1,506 \cdot 1 \\
1,446 \cdot 3\end{array}$ \\
\hline
\end{tabular}

(b) Females in England and Wales

\begin{tabular}{|c|c|c|c|c|}
\hline \multirow{2}{*}{$\begin{array}{l}\text { Cohort } \\
\text { born } \\
\text { around* }\end{array}$} & \multicolumn{4}{|c|}{ Age at Death } \\
\hline & $55-$ & $65-$ & $75-$ & $85+$ \\
\hline $\begin{array}{l}1863 \\
1868 \\
1873 \\
1878 \\
1883 \\
1888 \\
1893 \\
1898 \\
1903 \\
1908\end{array}$ & $\begin{array}{l}7 \cdot 9 \\
8 \cdot 6 \\
8 \cdot 6 \\
9 \cdot 6\end{array}$ & $\begin{array}{l}68 \cdot 8 \\
78 \cdot 2 \\
76 \cdot 4 \\
78 \cdot 2\end{array}$ & $\begin{array}{l}487 \cdot 3 \\
579 \cdot 1 \\
585 \cdot 6 \\
578 \cdot 3\end{array}$ & $\begin{array}{l}2,044 \cdot 7 \\
2,453 \cdot 8 \\
2,309 \cdot 2 \\
2,455 \cdot 5\end{array}$ \\
\hline
\end{tabular}

The 1863 cohort, for example, includes individuals born from 1856 to 1870 .

grouped in ten rather than five-year age groups. There is no evidence of a progressive change in the death rates experienced by successive cohorts.

\section{Discussion}

In England and Wales hospital discharge rates for Paget's disease are higher in the north and west than in the south and east (Fig. 1). In Scotland the discharge rates are high in the area around Glasgow (the West Central region) and low in the Highlands and in the Border Counties. Benn and Wood (1972) showed that mortality rates from Paget's disease in England and Wales followed a similar pattern to hospital discharge rates. Discharge and mortality statistics for a chronic disease with low mortality must be influenced by regional variations in many factors, for example migration, availability and utilization of hospital facilities, and death certification practices. However, the data suggest that there are regional variations in the prevalence of Paget's disease. Although Price (1962) suggested that there was an incidence gradient of Paget's disease in Britain, the disease decreasing in frequency from south to north, there has come from several sources the contrary impression of a lower incidence in the south than in the north. However, all clinical discussion of the frequency of Paget's disease is complicated by the relative infrequency of clinical as opposed to subclinical forms. For this reason a national survey is being planned in which the prevalence of subclinical Paget's disease in different regions will be determined from routine $x$-rays of elderly people.

Mortality rates from Paget's disease in England, Wales, and Scotland have declined in successive cohorts born after the 1880 s (Table III). There has also been a decline in mortality from malignant tumours of bone in persons aged 55 years and more, although this is seen in successive cohorts born after the 1870s. Osteogenic sarcoma is a complication of Paget's disease, and the increased mortality from bone tumours which occurs over the age of 40 is largely due to tumours associated with Paget's disease (Mackenzie, Court Brown, Doll, and Sissons, 1961). Although the accuracy of death certificate diagnoses of primary bone tumour is not high and decreases with the age of the patient (Mackenzie et al., 1961), the decline in certified deaths from malignant bone tumours accords with the decline in certified deaths from Paget's disease.

Court Brown, Doll, Heasman, and Sissons (1961) reviewed the geographical distribution of the deaths from primary bone tumours occurring in England and Wales during 1951-53. They concluded that there was no statistically significant variation overall but that 'several counties with low standardizeds mortalitieare grouped together 
in the southern and south-midland regions'. These lower bone tumour death rates in southern and eastern England would be expected from a lower prevalence of Paget's disease.

Death rates from fracture of the neck of the femur do not show the decline in successive cohorts seen in Paget's disease and bone tumours. However, mortality from fractures of the femur is higher in the north of England than in the south (Eddy, 1972). Most hip fractures occur in elderly people with osteoporosis (Nordin, 1971) and the epidemiology of death from fractured neck of femur will therefore reflect that of osteoporosis. Although osteoporosis and Paget's disease have a similar geographical distribution, the dissimilarity of their mortality trends suggests that the factors determining loss of bone tissue in old age are not those which determine the occurrence of Paget's disease.

The distribution of Paget's disease in England, Wales, and Scotland suggests an association with the industrialized areas of northern England and the Clyde. Another disease of bone which previously showed a similar distribution is rickets. Surveys carried out around the beginning of the century showed that rickets in Britain had its greatest prevalence in areas of high population density, predominantly the industrial centres which arose around the coal measures (Hess, 1930). In Scotland, Glasgow has always been noted for its high prevalence of rickets, whereas the disease was said to be rare in rural areas (Owen, 1889).

Available data suggest that the prevalence of Paget's disease throughout the world is related to latitude. The disease occurs throughout Europe and in Australia and New Zealand (Barry, 1969). Only isolated cases have been reported from the tropics. Although seemingly very rare in Africa, the disease is reported as having a similar frequency among American negroes as among whites (Rosenkrantz, Wolf, and Kaicher, 1952). Fifty years ago the world distribution of rickets was closely related to latitude and to the yearly average number of hours of sunshine, although this geographical association between rickets and deficiency of sunlight was modified by a number of factors such as urbanization, industrialization, and cultural practices affecting exposure of young children to sunlight (Hess, 1930).

The broad geographical association between the current distribution of Paget's disease and that of rickets at the beginning of the century leads to the suggestion that a predisposing factor to Paget's disease is vitamin $\mathbf{D}$ deficiency in childhood. Paget's disease has a higher incidence in males than in females and a similar male preponderance has been found in case series of rickets (Childs,
Cantolino, and Dyke, 1962). The current decline in Paget's disease mortality in successive cohorts in Britain is in accord with the declining incidence of rickets during this century. During the last decades of the nineteenth century and the early twentieth century there was a clinical impression that severe cases of rickets were being seen less frequently in Europe. Between the two world wars the incidence of rickets declined further, and during the second world war the methods introduced to supplement the vitamin $D$ intake of children in Britain finally led to rickets becoming a rare disease. If the secular trends in Paget's disease are following those of rickets then Paget's disease also will become rare by the end of this century.

Clearly the evidence for an association between Paget's disease and vitamin $\mathbf{D}$ deprivation in childhood is inconclusive. If Paget's disease was a sequel to severe rickets in childhood it is likely that clinical observation would have revealed this long ago, and one may suppose that the association is between Paget's disease and milder degrees of vitamin $\mathbf{D}$ deprivation. Further evidence may be sought by determining whether people with Paget's disease show the characteristics associated with childhood vitamin D deficiency, for example low social class, short stature, and childhoods spent in the poorer areas of industrial towns. A casecontrol study is being undertaken in Southampton to this purpose. The mechanism by which vitamin D deficiency and Paget's disease might be associated is a matter for speculation. Perhaps a reduced skeletal mass renders a person more vulnerable to the pathological effects of the disease, or perhaps the action of vitamin $D$ is more specific and its deficiency leads, for example, to changes in the inorganic element composition of bone which in some way predisposes to the disease.

The findings described in this paper may narrow the range of tenable aetiological hypotheses for Paget's disease. It is, for example, difficult to reconcile the geographical and secular variations described with the concept of the disease as an hereditary defect of connective tissue (Francis and Smith, 1974).

The data for England and Wales were provided by the Office of Population, Censuses, and Surveys and that for Scotland by the Home and Health Department. We are grateful for their help. It is also a pleasure to thank Miss Julie Beer for her statistical assistance.

\section{REFERENCES}

BARry, H. C. (1969). Paget's Disease of Bone. Livingstone, Edinburgh and London. 
BENN, R. T. and Wood, P. H. N. (1972). Mortality from Paget's disease of bone. Paper read to Society for Social Medicine meeting at Rennes.

Childs, B., Cantolino, S., and Dyke, M. L. (1962). Observations on sex differences in human biology. Bull. Johns Hopk. Hosp., 110, 134.

Collins, D. H. (1956). Paget's disease of bone. Incidence and subclinical forms. Lancet, 2, 51.

Court Brown, W. M., Doll, R., Heasman, M. A., and Sissons, H. A. (1961). Geographical distribution of primary tumours of bone in England and Wales. Brit. J. prev. soc. Med., 15, 167.

EDDY, T. P. (1972). Deaths from domestic falls and fractures. Brit. J. prev. soc. Med., 26, 173.

Francis, M. J. O. and SMith, R. (1974). Evidence of a generalized connective tissue defect in Paget's disease of bone. Lancet, $1,841$.

GuYer, P. B., Barker, D. J. P., and Gardner, M. J. (1974). Unpublished data.

Hess, A. F. (1930). Rickets, Including Osteomalacia and Tetany. Kimpton, London.
MACkenzie, A., Court Brown, W. M., Doll, R., and Sissons, H. A. (1961). Mortality from primary tumours of bone in England and Wales. Brit. med. J., $1,1782$.

Nordin, B. E. C. (1971). Clinical significance and pathogenesis of osteoporosis, Brit. med. J., 1, 571.

OWEN, I. (1889). Geographical distribution of rickets, acute and subacute rheumatism, chorea, cancer and urinary calculus in the British Islands. Brit. med. J., $1,113$.

Price, C. H. G. (1962). The incidence of osteogenic sarcoma in south-west England and its relationship to Paget's disease of bone. J. Bone Jt Surg., 44-B, 366.

Pygotr, F. (1957). Paget's disease of bone: the radiological incidence. Lancet, 1, 1170.

Registrar General for Scotland (1953-1971). Annual Reports 1951-70. HMSO, Edinburgh.

Registrar General's Statistical Review of England and Wales (1953-1973) pt I Tables, Medical, 1951-70. HMSO, London.

Rosenkrantz, J. A., Wolf, J., and Kaicher, J. J. (1952). Paget's disease (osteitis deformans). Arch. intern. Med., 90, 610. 